\title{
大学院教育に関する問題点
}

\section{一技術革新・国際化の時代への対応一 \\ Problems on Education in Graduate Schools}

- Accomodation to the Age of the Technological Revolution and Internationalization -

\section{古 賀 利 郎※ \\ Tosiro KOGA}

\begin{abstract}
At a turning point of the world situation as symbolized by a typical key word, the age of technological revolution, the international circumstances surrounding Japan in polytical, economical and other several respects are becoming not easy to manage. Only way for Japan, keeping her status established so far, to survive such the situation is considered to aim further progress in sicence and technology by herself as well as to get reputation in contiributions to the world peace and culture.

From the view-point mentioned above, problems of education for the next generation becomes of importance. We discuss in this monograph some of the problems in relation to the education in graduate schools of science and technology; that is, a problem of evalution of the present education, a problem concerning creativity in relation with the present state of education, and some of serious problems underlying the present graduate schools.
\end{abstract}

\section{あらまし}

技術革新の時代というキーワードで表象さ れるような世界の転換期において，日本をめ ぐる政治・経済その他もろもろの国際環境は きびしい。日本が現状を維持しつつ今後生き てゆくには，科学技術を独自に振興し，世界 の平和と文化に貢献する以外に道はないよう

※ 九州大学工学部情報工学教室

Faculty of Engineering, Kyushu University
に思われる。

上述のような立場から, 次世代の教育は重 要な問題となる。本論では, 理工系の大学院 での教育に関する幾つかの問題について論じ ている。すなわち, 現在の大学院教育の評価 の問題, 教育の現状との関連における創造性 の問題, および現在の大学院に内在するかな り深刻な問題について述べている。 


\section{1. 大学院教育問題に対する視点}

戦後，学制改革に伴い，新制の大学院が設 置されるようになって30年が経過した。この 間にわが国は，目覚ましい経済的発展を遂げ， 技術革新の時代，国際化の時代，情報化の時 代といった言葉で表象されるような変転の時 期を迎えている。てのようなときに，従来の 諸制度について反省してみるてとは, 至って 常識的なととと思われる。上述のような時代 の到来が，殊に科学技術の急速な進歩に根ざ しているととを念頭におき，われわ扎に身近 な理工系大学院の教育問題について省察する とき，単純に割り切る嫌いはあるか屯知れな いが，問題への視点が以下のように自ら定ま るように思われる。

資料に乏しく大きな人口を抱えたわが国の 将来を想うとき, かつての農業国に戻るとと は不可能に近く，科学技術の振興によって経 済的な繁栄を図りつつ, 国際的協調によって 平和な文化国家を維持してゆくことが，わが 国が独立国として生きてゆく最良の道である ことは異論のないとてろであろう。殊に，わ が国を取り巻く国際的環境が安穏としたもの でなく，わが国が否応なしに国際的対応を迫 られて打り，かつての状況が将来にわたり続 くであろうということを考えるとき，その感 を強くする。

以上のような観点に立つと，科学技術の面 で，工業製品の付加価値を高めるような独創 的技術の開発を行うことが大事であることは 無論であるが，さらに，わが国が世界の平和 と文化江貢献できるように，物心両面に扔い て不断の努力を続けることが重要であろう。 その際, 指導的役割の担い手として, 当然, 大学院終了者に対する期待は高まると考えら れ，したがって教育問題が重要性を帯びてく る。以下に大学院教育に関連した幾つかの問 題点を取りあげて，簡単な分析を行ってみる。

\section{2. 大学院教育に対する評価について}

周知のように，昭和 40 年代に経済発展の波 亿乗って大学の拡充が急速に進み, 紆余曲折 はあったあのの大学院修了者に対する需要は 漸増し, 最近, 一部にいわゆる構造不況の影 響は見られるが，需要に対し供給が大幅に不 足している状況である。とにかく大学院に対 する社会的評価は一応定まっているかに見受 けられる。

しかし，大学院における教育については， 批判的な論議もなされている。例えば，理工 系大学院の教育に押いては，一般に専攻分野 が自然科学に偏っていて閉鎖性があり, 研究 の成課・所産の社会的意義や, 社会に対する 科学者の責務といった問題に対し無関心であ ると。乙れに対し，理工系の教育に扔いてあ 人文科学的教養をつけさせ, 知的経験を深め させることによって, 国際的な科学の世界で 有能な指導者をつくり出す道が開けようと(1) また, 最近の学生に子供っぽさが目立つとい う指摘もなされている(2)。

戦後, 教育の大衆化が進んだてとは好まし いことに違いない。その反面, 中等教育以後 の教育の水準が旧制度時代に比へ低下したて とは致し方ないとしても, 教育の質が変って しまったととは，少なくとも次世代の指導層 の教育を考えるとき，果しててれでよいのか 之懸念される。乙の点に関しては, 欧米諸国 の教育の動向を調査し, 積極的に改善のため の参考にすべきであろう。

大学院教育の効果について大学が自ら評価 するのでは手前味噌になりかねない。大学外 から評価に関する論議が大いになされて当然 であろう。

\section{3. 創造性に関する問題——初等・中等教育 との関連}

教育問題を考えるとき，根本的であり，か つ最大の難問の一つは創造性に関する問題で 
あろう。特に独創的な技術の開発を希求する わが国にとって，乙の問題が重要であるとと は論をまたない。

大学院教育は高等教育の最終段階に当たり， 大部分の学生が, 年令的に頭脳の発達の最終 段階にあって，本来創造活動に向けて飛躍す べき重要な時期にあるといえる。実際に世界 的視野で眺めると，乙の時期に創造的な仕事 をし，文化に貢献した例は数多ある。日本人 は欧米人に比べ創造性に劣るということがし ばしば話題になるが，果しててれは本質的な てとであろうか。むしろ，悲観的になる前に， 社会の仕組, 教育のシステム, 環境等の何ら かの欠如によって，日本民族に潜在している はずの創造性の芽が踏みつぶされているので はないか，と疑ってみることが必要ではある まいか。

歴史的に優れた創造活動をした人達に共通 に見られる特徴は, 知的好奇心の強さであっ て，子供時代の好奇心がそのまま大人になっ ても持続されているといわれる。乙の点に関 し，現在わが国に露漫している小学生から高 校生に及ぶ詰め込み式学習はむしろ逆効果で, 害毒となっているのではないだろうか。

わが国の初等・中等教育の水準は，世界的 に最も高いといわれる。乙れは確かに教育の 効果には違いないが, 頭脳の発達の途中の段 階での事実に過ぎないことに注意を要する。

最近, 初等・中等教育に関する問題が議論 されるようになりつつあるが，上述のような 理由により，乙の問題は高等教育，したがっ て大学院教育と屯根本的に関係すると考えら れる。乙のことに関し, 小平邦彦博士による 重要な提言のまえがきを引用しておてう(3)。

「最近の子供は小学生のときから実によく勉 強する。にもかかわらず近年の大学生の学力 低下がいちじるしいのはなぜか。これは，現 在の初等・中等教育が原則を無視して多くの 教科を早くから教えているためではないだろ
うか。日本の教育を改めるには，全教科を統 制する基本方針の確立が急務である。」

\section{4. 大学院に関する問題点}

現在, 大学院の教育に関連して, 研究費, 研究旅費, 教員後継者の養成, 人事の交流等 に関し，多くのかなり深刻な問題が存在する。 これらの大部分は財政にからんでおり, 大学 独自には解決が難しい。

理工学系に関し, 最近大学と企業との間に 共同研究の道が開かれたてとは一つの進展で ある。しかし，企業の利益に結びつかない基 礎研究については, 問題は残されたままであ るととに留意すべきであろう。

わが国の将来によって重要な大学教員の後 継者となるべき優秀な人材の確保は，大学と 企業との待遇面での格差が大きく, 次第に困 難となりつつあるが, 学術振興会の特別研究 員制度の新設や，最近なされた提言(4)が採り あげられる方向にあることは喜ぶべきである。

\section{5.むすび}

教育に関する改革を成功させるには, 社会 全体のダイナミックス（dynamics）を考え に入れた対策が必要である。乙のととについ て論ずることは到底一個人の手に負えること ではない。就りに, 以上の小論に独断や偏 見の多々あり得ることをお断りし，寛怒をお 願いする。

\section{参考文献}

（1）田中靖政: 研究立国と二つの文化, 応用物理, 53，10，1984年 10 月, p. 826 .

(2) 青山和夫: 大学院改革の前提条件, 昭和 5355 年度文部省科学研究費補助金 (総合研究A), 大学院問題に関する調査研究別冊, 昭和 56 年 3 月, p. 15.

(3) 小平邦彦：原則を忘れた初等・中等教育 一何のため，そして誰のために急ぐのか一, 科学, $54,1,1984$ 年 1 月, p. 4 .

(4) 堀田凱樹: 若い世代の創造性のために, 科学, $\underline{54}, 2,1984$ 年 2 月, p. 65. 